\title{
Effects of macauba cake on profile of rumen protozoa of lambs
}

\section{Antonio Carlos Ramos dos Santos ${ }^{1}$, Rafael Alves de Azevedo ${ }^{2}$, Gercino Ferreira Virginio Júnior ${ }^{1}$, Norberto Mario Rodriguez ${ }^{3}$, Eduardo Robson Duarte ${ }^{1}$, Luciana Castro Geraseev ${ }^{1 *}$}

\footnotetext{
1 Universidade Federal de Minas Gerais, Instituto de Ciências Agrárias, Montes Claros, MG, Brazil.

${ }^{2}$ Universidade Federal de Minas Gerais, Programa de Pós-graduação em Zootecnia, Belo Horizonte, MG, Brazil.

${ }^{3}$ Universidade Federal de Minas Gerais, Escola de Veterinária, Departamento de Zootecnia, Belo Horizonte, MG, Brazil.
}

\begin{abstract}
The present study was conducted to determine the effects of the inclusion of macauba cake, from biodiesel processing, on profile of rumen protozoa of Santa Ines lambs. Twenty-four lambs were randomized in block design supplemented with macauba cake at $0,100,200$, and $300 \mathrm{~g} / \mathrm{kg}$ of dry weight of the diet. Concentrations of small, medium, and large protozoa had quadratic relationships with inclusion of macauba cake, with maximum protozoa occurring at $100 \mathrm{~g} / \mathrm{kg}$. High genus diversity occurred in rumen fluid of lambs that did not feed macauba cake, comprising 13 protozoa genera. However, only the genera Isotricha, Charonina, Entodinium, Diplodinium, Eodinium, Diploplastron, and Polyplastron were detected in lambs fed $300 \mathrm{~g} / \mathrm{kg}$ macauba cake, indicating that these protozoa were resistant to the effects of the cake. Addition of macauba cake levels greater than $100 \mathrm{~g} / \mathrm{kg}$ show antiprotozoal effect in the rumen.
\end{abstract}

Key Words: Acrocomia aculeata, byproduct, protozoa diversity, sheep

\section{Introduction}

Macauba (Acrocomia aculeata (Jacq.) Lodd. ex Mart.) is an oleaginous palm tree native to dry hillsides and open forests from Central America to Southern Brazil. It is highly productive and adapted to semiarid ecosystems. The oil of macauba may be used to produce biodiesel, cosmetics, and foods (Coimbra and Jorge, 2012; Souza et al., 2016). During the process of oil extraction by hydraulic pressing, large quantities of biomass residue are generated, representing $500 \mathrm{~g} / \mathrm{kg}$ of the processed fruit. This residual biomass, macauba cake, contains high levels of fiber and lipids and it can be indicated as an alternative ruminant feed (Rufino et al., 2011; Azevedo et al., 2013).

Feeds rich in lipids contribute to energy supply of highproducing animals, optimizing the use of the digestible energy (Hess et al., 2008). However, high lipid level in the ruminant diets $(>70 \mathrm{~g} / \mathrm{kg}$ of dry matter) can inhibit

Received: June 14, 2016

Accepted: November 29, 2016

*Corresponding author: Igeraseev@gmail.com

http://dx.doi.org/10.1590/S1806-92902017000300010

How to cite: Santos, A. C. R.; Azevedo, R. A.; Virginio Júnior, G. F.; Rodriguez, N. M.; Duarte, E. R. and Geraseev, L. C. 2017. Effects of macauba cake on profile of rumen protozoa of lambs. Revista Brasileira de Zootecnia 46(3):251-256.

Copyright (C) 2017 Sociedade Brasileira de Zootecnia. This is an Open Access article distributed under the terms of the Creative Commons Attribution License (http://creativecommons.org/licenses/by/4.0/), which permits unrestricted use, distribution, and reproduction in any medium, provided the original work is properly cited. rumen fermentation (Palmquist and Jenkins, 1980) and, consequently, impair performance of finishing animals. According to Byers and Schelling (1989), this inhibition could be due to the reduction of the microbial adhesion in vegetal fiber or, possibly, a direct toxic effect of unsaturated fatty acids on rumen microbes via alteration in the lipid composition and physicochemical properties of the microbial cellular membranes (Jenkins, 1993). The Gram-positive bacteria (Nagaraja et al., 1997) and ciliate protozoa (Doreau and Ferlay, 1995) are the most sensitive microorganisms to toxic effect of unsaturated fatty acids.

Ciliate protozoa suppression may reduce methane production and increase the efficiency of energy utilization and the microbial protein levels for ruminant, improving animal production (Doreau and Ferlay, 1995; Eugene et al., 2004; Martin et al., 2010), but it also negatively affects fiber digestion, which is the main function of the rumen (Mosoni et al., 2010).

Macauba cake might alter the rumen profile of protozoa populations due to the high levels of lipid and fiber contents. In goats fed macauba cake inclusion at 100 and $150 \mathrm{~g} / \mathrm{kg}$ of dry matter (Rufino et al., 2011), the concentration of medium protozoa populations increased significantly. However, the effects of macauba cake inclusion in the rumen microbial ecosystem of sheep, as well as their relation on animal performance, are not known. This research evaluated the effects of macauba cake inclusion on rumen protozoa populations of confined lambs. 


\section{Material and Methods}

All animal experimental procedures were performed according to the Institutional Committee on animal use Ethics under case no. 46/2009.

Twenty-four Santa Ines lambs (average age $5 \pm 0.1$ months (mean $\pm \mathrm{SD}$ ) and weighing $23.9 \pm 0.6 \mathrm{~kg}$ ) were randomly assigned to the four treatment diets in a randomized block design. Blocks were formed according to their initial live weight and lambs were located in individual cages of $1.10 \times 1.10 \mathrm{~m}$ equipped with waterers and feed bunks.

The experimental period lasted 70 days, including 10 days for adaptation to installation and diets. At the beginning of the adaptation period, the lambs were individually identified, treaded with anthelmintic (Aldazol $10 \mathrm{CO}^{\circledR}$ laboratory Vallée SA, Montes Claros, Minas Gerais, Brazil), and immunized for clostridiosis (POLI$\mathrm{R}^{\circledR}$ laboratory Vallée SA, Montes Claros, Minas Gerais, Brazil).

Four experimental diets were formulated according to National Research Council (NRC, 2007) for a weight gain of $200 \mathrm{~g}$ per day; levels of macauba cake in the diet were: $0,100,200$, and $300 \mathrm{~g} / \mathrm{kg}$ of dry matter (DM) (Table 1). Forage and concentrate were mixed and fed twice daily at 07.00 and $16.00 \mathrm{~h}$. The feeding rate was adjusted daily to yield refusal rates of $\sim 200 \mathrm{~g} / \mathrm{kg}$ of total feed delivered. Refusals were removed before the morning feeding and weighed daily to determine intake. Animals were weighted at the start of the experiment and then weekly before morning feeding.

Lambs were subjected to visual observation at the beginning, middle, and end of the experiment with trained observers positioned strategically so as not to disturb the lambs. Observations occurred every 5 min during $24 \mathrm{~h}$, divided into three periods of $8 \mathrm{~h}$ to determine the time spent on eating, ruminating, and idling, according to Johnson and Combs (1991). For nocturnal observations, the environment was maintained with artificial lighting.

Samples of diets and refusals were daily collected, identified, and stored in a freezer at $-20^{\circ} \mathrm{C}$ for later laboratory analysis. All samples were pre-dried in a ventilated oven at $55{ }^{\circ} \mathrm{C}$, ground to pass through $1-\mathrm{mm}$ sieve screen, using a laboratory mill, and stored in airtight plastic containers until analysis.

Samples were analyzed according to the Association of Official Analytical Chemists (AOAC, 1998) for DM (method 934.01), ash (method 942.05), crude protein (CP; method 954.01), and ether extract (EE; method 920.39). Neutral detergent fiber (aNDF; Van Soest et al., 1991) and acid detergent fiber (ADF) were analized (AOAC, 1998, method 973.18) using ANKOM200 Fiber Analyzer unit (ANKOM Technology Corporation, Fairport, New York, USA). Sodium sulphite and alpha amylase were used in the determination of aNDF. Non-fiber carbohydrates were calculated as: $\mathrm{NFC}=100-(\% \mathrm{aNDF}+\% \mathrm{EE}+\% \mathrm{CP}+$ $\%$ Ash), according to NRC (2001). The DM, organic matter (OM), CP, EE, NFC, and aNDF intakes were

Table 1 - Ingredients and chemical composition ( $\mathrm{g} / \mathrm{kg}$ of dry matter) of the diets and macauba cake

\begin{tabular}{|c|c|c|c|c|c|}
\hline \multirow{2}{*}{ Item } & \multicolumn{4}{|c|}{ Level of dietary macauba cake $(\mathrm{g} / \mathrm{kg})$} & \multirow{2}{*}{ Macauba cake ${ }^{1}$} \\
\hline & 0 & 100 & 200 & 300 & \\
\hline \multicolumn{6}{|l|}{ Ingredient } \\
\hline Soybean meal (450 g CP/kg) & 149.8 & 153.0 & 156.1 & 159.3 & - \\
\hline Corn grain & 486.5 & 384.0 & 281.4 & 178.9 & - \\
\hline Cottonseed seed & 50 & 50 & 50 & 50 & - \\
\hline Macauba cake & 0 & 100 & 200 & 300 & - \\
\hline Sodium chloride & 2.8 & 2.8 & 2.8 & 2.8 & - \\
\hline Vitamin-mineral mix ${ }^{2}$ & 0.2 & 0.2 & 0.2 & 0.2 & - \\
\hline \multicolumn{6}{|l|}{ Chemical composition } \\
\hline Dry matter & 729.2 & 739.4 & 743.0 & 748.0 & 949.6 \\
\hline Crude protein & 150.1 & 158.8 & 158.1 & 157.4 & 81.8 \\
\hline Non-fibrous carbohydrates & 447.2 & 381.4 & 319.2 & 284.4 & 113.9 \\
\hline
\end{tabular}


calculated by the difference of the daily weight offered and refused by lambs. Fatty acid composition of the macauba cake was determined according to Machmu Èller and Kreuzer (1999), subsequent to chloroformmethanol extraction $(2: 1, \mathrm{v} / \mathrm{v})$ as methyl esters by an HP 5890A gas chromatograph (Hewlett-Packard, Avondale, Pennsylvania, USA), equipped with a Supelcowax 10column (fused silica capillary column, $30 \mathrm{~m} \times 0.32 \mathrm{~mm}$ ).

At the end of the experiment, the animals were fasted for $14 \mathrm{~h}$. Immediately after slaughter, rumen fluid was obtained from each lamb by a $10-\mathrm{cm}$ incision in the ventral rumen sac. Approximately $15 \mathrm{~mL}$ was collected with sterile inverted pipettes coupled to a rubber pipettor and allocated in test tubes and immediately transported in isothermal boxes at $4{ }^{\circ} \mathrm{C}$ to the laboratory. Tubes were homogenized in a vortex for $1 \mathrm{~min}$ and an aliquot of $1000 \mu \mathrm{L}$ was transferred to tubes containing $9 \mathrm{~mL}$ of $10 \%$ formalin $(10 \mathrm{~mL} / 100 \mathrm{~mL}$ distilled water) for preservation of protozoa. Subsequently, serial dilutions in saline solution were conducted in Sedgewick Rafter counting chambers (S52 glass, PyserSGI, Edenbridge, Kent, UK) for determination of numbers of small (up to $40 \times 60 \mu \mathrm{m}$ ), medium (up to $100 \times 150 \mu \mathrm{m}$ ), and large (larger than $100 \times 150 \mu \mathrm{m}$ ) protozoa per $\mathrm{mL}$ of rumen fluid by light microscopy at $10 \mathrm{x}$ magnification (Dirksen, 1993). Two subsamples of $1 \mathrm{~mL}$ were evaluated, counting all 50 columns of the Sedgewick Rafter chambers and the average represented individual count for each animal.

For protozoa identification, subsamples were placed on slides with cover slips with a drop of Lugol iodine solution. Identifications were performed in optical microscope at $40 \mathrm{x}$ objective to characterize a minimum of 200 protozoa per lamb (Rufino et al., 2011). In this study, 9,345 protozoa were evaluated and genera classified in accordance with the morphologic characteristics described by Dehority (1993).

Results were analyzed according to the GLM procedure of SAS (Statistical Analysis System, version 9.1) in a randomized block design to test effects of macauba cake inclusion.

Protozoa counts were analysed after logarithmic transformation $(\log 10)$ and regression analysis was performed to determine the relationship of macauba cake level of the diets and feed intake, ruminating time, concentrations of small, medium, large, and total protozoa. For analysis of the population profiles, the relative values (counts/100) of the genus identified were subjected to regression analysis.

In the regression study, the model was: $\gamma \mathrm{ij}=\beta 0+\beta 1 \mathrm{xi}+$ $\beta 2 \mathrm{xi} 2+\beta 3 \mathrm{xi} 3+\alpha \mathrm{j}+\varepsilon \mathrm{ij}$, in which $\gamma \mathrm{ij}=$ dependent variables; $\beta=$ regression coefficients; $x i=$ macauba cake levels; $\alpha j=$ deviations from the regression; and $\varepsilon i j=$ random residual error.

\section{Results}

There was no difference among treatments for weight gain and intake of DM, OM, and CP (Table 2). There was an increase in the intake of EE and aNDF $(\mathrm{P}<0.01)$ and in time spent ruminating $(\mathrm{P}=0.04)$ and a decrease in intake of NFC $(\mathrm{P}<0.01)$ with inclusion of macauba cake.

The concentration of ciliate protozoa ranged from 1.35 to $4.24 \times 10^{6} / \mathrm{mL}$ of rumen fluid (Table 3 ). Concentrations of small, medium, and large protozoa, as well as the total, were maximal at $100 \mathrm{~g} / \mathrm{kg}$ level in the diet. Above $100 \mathrm{~g} / \mathrm{kg}$, the protozoa concentrations decreased substantially. Intake of 200 and $300 \mathrm{~g} / \mathrm{kg}$ reduced the ruminal protozoa population by $26 \%$ and $50 \%$ (in relation to diet without macauba cake), respectively.

The genera of the subclasses Holotricha (Buetschilia and Isotricha) and Entodiniomorpha (Charonina, Entodinium, Diplodinium, Eodinium, Eremoplastron, Eudiplodinium, Diploplastron, Polyplastron, Ostracodinium, Metadinium, and Enoploplastron) were identified in sheep in the diet without macauba cake, with Entodiniomorphs representing more than $95 \%$ of the fauna. With inclusion of macauba cake, there was a reduction in the diversity of fauna $(\mathrm{P}=0.05)$ (Table 4), with only seven protozoa genera in the rumen contents of lambs fed $300 \mathrm{~g} / \mathrm{kg}$ (Isotricha, Charonina, Entodinium, Diplodinium, Eodinium, Diploplastron, and Polyplastron).

Entodinium spp. was predominant in controls, with 53 counts/100 of the identified ciliate protozoa and in the $100 \mathrm{~g} / \mathrm{kg}$ macauba cake group with 43 counts $/ 100$. Charonina spp. was the most frequent in diets of $200 \mathrm{~g} / \mathrm{kg}$ and $300 \mathrm{~g} / \mathrm{kg}$ macauba cake at 42 and 50 counts $/ 100$ of ciliates, respectively. Increases in the level of macauba cake resulted in increase $(\mathrm{P}<0.01)$ in the proportion of Charonina spp. and Diplodinium spp. and decreases $(\mathrm{P}<0.01)$ in the proportion of Entodinium spp., indicating this genus as the most sensitive to antiprotozoal activity of the macauba cake.

\section{Discussion}

The macauba cake inclusion did not alter the intake of DM, OM, and CP (Table 2), even when considering the increase of aNDF (320.9 to $620.3 \mathrm{~g} / \mathrm{kg} \mathrm{DM}$ ) provided by macauba cake inclusion. Possibly, the small particle size of the fiber constitution of the macauba cake favored the normal traffic of fibers on digestive tract and did not 
promote repletion of the pre-stomachs. Burke et al. (2011) and Nunes et al. (2011) reported that lambs fed different levels of palm kernel expeller, an aNDF-rich feed, showed no significant differences between diets for total DM intake and DM intake adjusted for metabolic weight.

Van Wyngaard et al. (2015) reported that, recently, high maize prices have forced nutritionists to partly replace maize with byproduct feeds. Macauba cake is a fiber-fat source, which can be used to replace maize in diets. The effects of substitution of starch by fiber-fat source depend on the fiber content and oil present in the byproduct. According to Jesus et al. (2012), high levels of digestible fiber increase the population of the rumen protozoa, while the presence of lipids and other compounds inhibits the growth of these microorganisms.

Although levels above $100 \mathrm{~g} / \mathrm{kg}$ of macauba cake induced higher aNDF intake and longer rumination time, there was substantial decline in the total number of protozoa (Table 3), possibly due to increase in intake of EE from macauba cake. The latter could have caused toxic effect on ciliate protozoa due to its high levels of unsaturated fatty acids, considerable levels of lauric $\left(\mathrm{C}_{12: 0}\right)$ and myristic $\left(\mathrm{C}_{14: 0}\right)$ acids (Table 1). Both in vitro and in vivo studies have demonstrated protozoa sensitive to linolenic $\left(\mathrm{C}_{18: 3}\right)$, linoleic $\left(\mathrm{C}_{18: 2}\right)$, and oleic $\left(\mathrm{C}_{18: 1}\right)$ unsaturated fatty acids, in this order (Machmüller et al., 1998; Hristov et al., 2004), and to lauric and myristic saturated fatty acids (Dohme et al., 1999; Faciola et al., 2013), with greater antiprotozoal effects observed with medium chain saturated lipids (Machmüller et al., 1998).

There is consensus that lipids can promote antiprotozoal effects. However, the mechanisms by which it occurs are still unclear. Jenkins (1993) proposed that antimicrobial effects of lipids in the rumen may be similar to cytotoxic effects of fatty acids on biological membrane functions, such as oxidative phosphorylation. Other mechanisms for lipid toxicity that have been proposed were: perturbation of ether-lipid metabolism; inhibition of a specific-acyl-CoAacyltransferase, an enzyme involved in lipid-remodelling (Lux et al., 2000); and inhibition of methylation of phosphatidylcholine, which would block neo synthesis (Lira et al., 2001). Even though these studies were in flagellated protozoa, which have different membrane structure than rumen ciliates, these mechanisms may shed light into possible lipid toxicity mechanisms in rumen ciliates (Faciola et al., 2013).

In the present study, low concentration of Isotricha spp. was observed (Table 4), suggesting an escape of this or other Holotricha from rumen to the reticle during the obligatory fasting period that preceded the animal slaughter. These protozoa translocations from the rumen to the reticle during fasting and the subsequent migration from the reticle to the rumen after animal feed have been reported in cattle

Table 2 - Live weight gain, ruminating time, and feed intake of sheep fed different levels of macauba cake inclusion in the diet

\begin{tabular}{|c|c|c|c|c|c|c|c|}
\hline \multirow{2}{*}{ Item } & \multicolumn{4}{|c|}{ Level of dietary macauba cake $(\mathrm{g} / \mathrm{kg})$} & \multirow{2}{*}{ SEM } & \multicolumn{2}{|c|}{ P-value } \\
\hline & 0 & 100 & 200 & 300 & & Linear & Quadratic \\
\hline Initial live weight (kg) & 23.6 & 24.2 & 23.7 & 24.1 & 0.6 & 0.83 & 0.94 \\
\hline Final live weight $(\mathrm{kg})$ & 35.9 & 36.2 & 35.9 & 35.4 & 0.9 & 0.84 & 0.84 \\
\hline Live weight gain (g/d) & 205 & 200 & 203 & 188 & 10 & 0.57 & 0.80 \\
\hline Ruminating time $(\mathrm{min} / \mathrm{d})$ & 450 & 512 & 592 & 561 & 24 & 0.04 & 0.31 \\
\hline \multicolumn{8}{|l|}{ Feed intake (g/d) } \\
\hline Dry matter & 1094 & 1093 & 1133 & 1179 & 48.1 & 0.32 & 0.72 \\
\hline Organic matter & 1056 & 1048 & 1079 & 1114 & 45.6 & 0.47 & 0.73 \\
\hline Crude protein & 157 & 176 & 179 & 185 & 15.3 & 0.10 & 0.57 \\
\hline Ether extract & 42 & 56 & 72 & 80 & 4.1 & $<0.01$ & 0.46 \\
\hline Non-fibrous carbohydrates & 543 & 450 & 381 & 359 & 19.4 & $<0.01$ & 0.19 \\
\hline Neutral detergent fiber & 314 & 366 & 447 & 489 & 18.3 & $<0.01$ & 0.83 \\
\hline
\end{tabular}

SEM - standard error of the mean.

Table 3 - Concentrations of ciliate protozoa $\left(\times 10^{5} / \mathrm{mL}\right.$ of rumen fluid $)$ of sheep fed different levels of macauba cake inclusion in the diet

\begin{tabular}{|c|c|c|c|c|c|c|c|}
\hline \multirow{2}{*}{ Item } & \multicolumn{4}{|c|}{ Level of dietary macauba cake $(\mathrm{g} / \mathrm{kg})$} & \multirow{2}{*}{ SEM } & \multicolumn{2}{|c|}{ P-value } \\
\hline & 0 & 100 & 200 & 300 & & Linear & Quadratic \\
\hline \multicolumn{8}{|l|}{ Protozoa $^{1}$} \\
\hline Small & 12.7 & 14.9 & 10.0 & 5.93 & 0.70 & $<0.01$ & $<0.01$ \\
\hline Medium & 14.1 & 27.0 & 9.77 & 7.46 & 1.59 & $<0.01$ & $<0.01$ \\
\hline Large & 0.14 & 0.47 & 0.09 & 0.06 & 0.04 & $<0.01$ & $<0.01$ \\
\hline Total & 26.9 & 42.4 & 19.9 & 13.5 & 2.26 & $<0.01$ & $<0.01$ \\
\hline
\end{tabular}

${ }^{1}$ Small (up to $40 \times 60 \mu \mathrm{m}$ ), medium (up to $100 \times 150 \mu \mathrm{m}$ ), and large (larger than $100 \times 150 \mu \mathrm{m}$ ).

SEM - standard error of the mean. 
Table 4 - Genus profile (counts/100) of rumen protozoa in sheep fed different levels of macauba cake in the diet

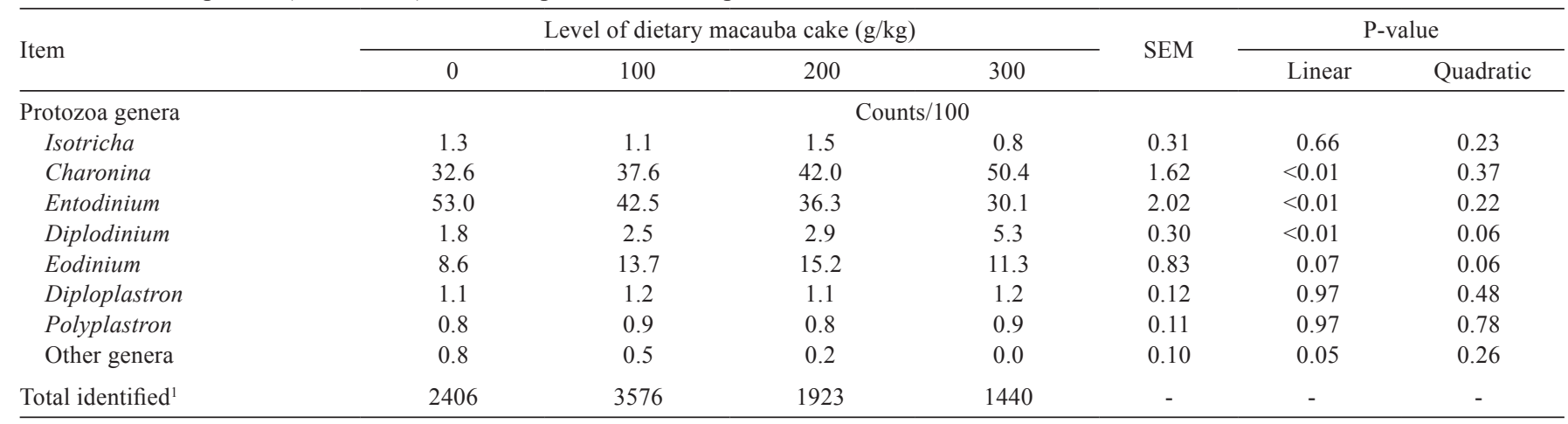

${ }^{1}$ Total number of protozoa identified by treatment group.

SEM - standard error of the mean.

(D’Agosto and Guedes, 2000; Martinele et al., 2007). Similar to our previous observations in goat and cow (Rufino et al., 2011; Dos Santos et al., 2015), Entodinium was the main genus, constituting more than $40 \%$ of the total protozoa in the rumen of the lambs fed or not $100 \mathrm{~g} / \mathrm{kg}$ macauba cake. However, in sheep fed 200 or $300 \mathrm{~g} / \mathrm{kg}$, Entodinium spp. did not predominate among rumen ciliates, being supplanted by Charonina spp. (Table 4). This suggests that Entodinium spp. is more sensitive to toxic effects of macauba cake lipids in the rumen. According to Williams (1986), Entodinium spp., which consumes fiber, normally readily uses available carbohydrates. Therefore, the decrease in NFC intake with higher macauba cake inclusion could have also contributed to the reduction of this genus. This reduction could have positive effects, since methanogens were found living in the cytoplasm of Entodinium spp., using $\mathrm{H}_{2}$ evolved by the host ciliate to form methane (Finlay et al., 1994). Increases in the macauba cake level also resulted in increases $(\mathrm{P}<0.01)$ in the proportion of Charonina spp. and Diplodinium spp., suggesting these genera as the most tolerant to antiprotozoal effects of macauba cake lipids in the rumen. This may also be associated with increased aNDF intake since entodiniomorphs can adhere to fibers, engulf particulate matter, and may produce cellulases and xylanases (Williams and Coleman, 1985).

The antiprotozoal activity of macauba cake could have positive effect on efficiency of dietary energy use because protozoa may be responsible for up to $37 \%$ of methanogenesis (Finlay et al., 1994) and, thus, reduction in ciliates may result in lower energy loss from the rumen.

\section{Conclusions}

Macauba cake offered up to $300 \mathrm{~g} / \mathrm{kg}$ does not alter feed intake of Santa Ines lambs; however, it alters ruminal protozoa concentrations. The maximum protozoa population occurs at $100 \mathrm{~g} / \mathrm{kg}$ and, above this level, it promotes antiprotozoal effect with reduction of the genus diversity.

\section{Acknowledgments}

The authors thank Conselho Nacional de Desenvolvimento Científico e Tecnológico (CNPq), Cooperativa de Pequenos Produtores de Riacho D'Antas, Fundação de Amparo à Pesquisa do Estado de Minas Gerais (APQ-01219-08), and Pró-Reitoria de Pesquisa da Universidade Federal de Minas Gerais.

\section{References}

AOAC - Association of Official Analytical Chemist. 1998. Official methods of analysis. AOAC, Gaithersburg, MP.

Azevedo, R. A.; Dos Santos, A. C. R.; Ribeiro Jr, C. S.; Bicalho, F. L.; Bahiense, R. N.; Araújo, L. and Geraseev, L. C. 2013. Ingestive behavior of dairy cows fed with macauba meal. Ciência Rural 43:1485-1488

Byers, F. M. and Schelling, G. T. 1989. Lipids in ruminant nutrition. p.298-312. In: The ruminant animal: Digestive physiology and nutrition. Church, D. C., ed. Prentice Hall, Englewood Cliffs, New Jersey, USA.

Burke, J. L.; Dias, F. N.; Pacheco, D.; Lopez-Villalobos, N. and Holmes, C. W. 2011. The apparent digestibility of palm kernel expeller (PKE) consumed by pasture-fed sheep. Proceedings of the New Zealand Society of Animal Production 71:223-228.

Coimbra, M. C. and Jorge, N. 2012. Fatty acids and bioactive compounds of the pulps and kernels of Brazilian palm species, guariroba (Syagrus oleraces), jerivá (Syagrus romanzoffiana) and macaúba (Acrocomia aculeata). Journal of the Science of Food and Agriculture 92:679-684.

D'Agosto, M. and Guedes, P. M. M. 2000. Caracterização das populações de ciliados (Protista, Ciliophora) do rúmen de bovinos de corte no estado de Minas Gerais, Brasil. Revista Brasileira de Zoociências 2:81-90.

Dehority, B. A. 1993. Laboratory manual for classification and morphology of rumen ciliate protozoa. CRC Press, Boca Raton, Florida, USA. 
Dirksen, G. 1993. Sistema digestivo. p.166-169. In: Rosenberger: Exame clínico dos bovines. Dirksen, G.; Grunder, H. D. and Stöber, M., eds. Guanabara Koogan, Rio de Janeiro.

Dohme, F.; Machmüller, A.; Estermann, B. L.; Pfister, P.; Wasserfallen, A. and Kreuzer, M. 1999. The role of the rumen ciliate protozoa for methane suppression caused by coconut oil. Letters in Applied Microbiology 29:187-192.

Doreau, M. and Ferlay, A. 1995. Effect of dietary lipids on nitrogen metabolism in the lumen: a review. Livestock Production Science 43:97-110.

Dos Santos, A. C. R.; Magalhães, D. Q.; Azevedo, R. A.; Vieira, I. L. N. L.; França, D. E. G.; Geraseev, L. C. and Duarte, E. R. 2015. The effect of macauba meal inclusion in the ruminal protozoa population of dairy cows. Arquivo Brasileiro de Medicina Veterinária e Zootecnia 67:1653-1659.

Eugene, M.; Archimede, H. and Sauvant, D. 2004. Quantitative metaanalysis on the effects of defaunation of the rumen on growth, intake and digestion in ruminants. Livestock Production Science 85:81-97.

Faciola, A. P.; Broderick, G. A.; Hristov, A. and Leão, M. I. 2013. Effects of lauric acid on ruminal protozoal numbers and fermentation pattern and milk production in lactating dairy cows. Journal of Animal Science 91:363-373.

Finlay, B. J.; Esteban, G.; Clarke, K. J.; Williams, A. G.; Embley, T. M. and Hirt, R. P. 1994. Some rumen ciliates have endosymbiotic methanogens. FEMS Microbiology Letters 117:157-161.

Hess, B. W.; Moss, G. E. and Rule, D. C. 2008. A decade of developments in the area of fat supplementation research with beef cattle and sheep. Journal of Animal Science 86:188-204.

Hristov, A. N.; Ivan, M. and McAllister, T. A. 2004. In vitro effects of individual fatty acids on protozoal numbers and on fermentation products in ruminal fluid from cattle fed a high-concentrate, barley-based diet. Journal of Animal Science 82:2693-2704.

Jenkins, T. C. 1993. Lipid-metabolism in the rumen. Journal of Dairy Science 76:3851-3863.

Jesus, L. P.; Cabral, L. S.; Espinosa, M. M.; Abreu, J. G.; Zervoudakis, J. T. and Morenz, M. J. F. 2012. Modelagem estatística para estimação da população de protozoários ruminais em função da relação volumoso:concentrado na dieta e da presença de aditivos. Revista Brasileira de Saúde e Produção Animal 13:97-109.

Johnson, T. R. and Combs, D. K. 1991. Effects of prepartum diet, inert rumen bulk, and dietary polyethylene glycol on dry matter intake of lactating dairy cows. Journal of Dairy Science 74:933-944.

Lira, R.; Contreras, L. M.; Rita, R. M. and Urbina, J. A. 2001. Mechanism of action of anti-proliferative lysophospholipid analogues against the protozoan parasite Trypanosoma cruzi: potentiation of in vitro activity by the sterol biosynthesis inhibitor ketoconazole. Journal of Antimicrobial Chemotherapy 47:537-546.

Lux, H.; Heise, N.; Klenner, T.; Hart, D. and Opperdoes, F. R. 2000. Ether-lipid (alkyl-phospholipid) metabolism and the mechanism of action of ether-lipid analogues in Leishmania. Molecular and Biochemical Parasitology 111:1-14.
Machmu Èller, A. and Kreuzer, M. 1999. Methane suppression by coconut oil and associated effects on nutrient and energy balance in sheep. Canadian Journal of Animal Science 79:65-72.

Machmüller, A.; Ossowski, D.A.; Wanner, M. and Kreuzer, M. 1998. Potential of various fatty feeds to reduce methane release from rumen fermentation in vitro (Rusitec). Animal Feed Science Technology 71:117-130.

Martin, C.; Morgavi, D. P. and Doreau, M. 2010. Methane mitigation in ruminants: from microbe to the farm scale. Animal 4:351-365.

Martinele, I.; Detoni, M.; Rust, N. and D’Agosto, M. 2007. Protozoários ciliados (Protista, Ciliophora) no conteúdo do rúmen e do retículo de bovinos. Revista Brasileira de Zoociências 9:63-66.

Mosoni, P.; Martin, C.; Forano, E. and Morgavi, D. P. 2010. Longterm defaunation increases the abundance of cellulolytic ruminococci and methanogens but does not affect the bacterial and methanogen diversity in the rumen of sheep. Journal of Animal Science 89:783-791.

Nagaraja, T. G.; Newbold, C. J.; Ven Nevel, C. J. and Demeyer D. I. 1997. Manipulation of ruminal fermentation. p.523-632. In: The rumen microbial ecosystem. Hobson, P. and Stewart, C. S., eds. Blackie Academic and Professional, London, UK.

NRC - National Research Council. 2001. Nutrient requirements of dairy cattle. 7th rev. ed. National Academy Press, Washington, DC, USA.

NRC - National Research Council. 2007. Nutrient requirements of small ruminants: Sheep, goats, cervids and New World camelids. 6th ed. National Academy Press, Washington, DC, USA.

Nunes, A. S.; Oliveira, R. L.; Borja, M. S.; Bagaldo, A. R.; Macome, F. M.; Jesus, I. B.; Silva, T. M.; Barbosa, L. P. and Garcez Neto, A. F. 2011. Consumo, digestibilidade e parâmetros sanguíneos de cordeiros submetidos a dietas com torta de dendê. Archivos de Zootecnia 60:903-912.

Palmquist, D. L. and Jenkins, T. C. 1980. Fat in lactation rations: review. Journal of Dairy Science 63:1-14.

Rufino, L. M. A.; Barreto, S. M. P.; Duarte, E. R.; Geraseev, L. C.; Dos Santos, A. C. R. and Jaruche, Y. G. 2011. Effects of inclusion of macaúba cake on ruminal protozoa population of goats. Revista Brasileira de Zootecnia 40:899-903.

Souza, G. K.; Scheufele, F. B.; Pasa, T. L. B.; Arroyo, P. A. and Pereira, N. C. 2016. Synthesis of ethyl esters from crude macauba oil (Acrocomia aculeata) for biodiesel production. Fuel 165:360-366

Van Soest, P. J.; Robertson, J. B. and Lewis, B. A. 1991. Methods for dietary fiber, neutral detergent fiber, and nonstarch polysaccharides in relation to animal nutrition. Journal of Dairy Science 74:3583-3597.

Williams, A. G. 1986. Rumen holotrich ciliate protozoa Microbiological Reviews 50:25-49.

Williams, A. G. and Coleman, G. S. 1985. Hemicellulose-degrading enzymes in rumen ciliate protozoa. Current Microbiology 12:85-90.

Van Wyngaard, J. D. V.; Meeske, R. and Erasmus, L. J. 2015. Effect of palm kernel expeller as supplementation on production performance of Jersey cows grazing kikuyu-ryegrass pasture. Animal Feed Science and Technology 199:29-40. 